\title{
Clutch and egg size variation in the Marsh Harrier Circus aeruginosus in eastern Poland
}

\author{
Variation $i$ kull- och äggstorlek hos brun kärrhök Circus aeruginosus $i$ östra Polen
}

\author{
MARCIN POLAK
}

\begin{abstract}
The main aim of this study was to examine how clutch size and season influenced egg size in a population of Marsh Harriers Circus aeruginosus in eastern Poland. The Marsh Harriers nested in small, isolated patches of reed belts surrounding fish ponds. A total of 328 eggs from 70 clutches were measured during four nesting seasons (2005-2008). Average clutch size was $4.69 \pm 0.71$ eggs and did not vary between years; the modal clutch size was 5 eggs. Mean values of the egg dimensions

were: egg length $=48.60 \pm 1.78 \mathrm{~mm}$; egg breadth $=38.36$ $\pm 1.13 \mathrm{~mm}$; egg volume $=36.53 \pm 2.99 \mathrm{~cm}^{3}$. There was a strong correlation between egg length and egg breadth. The number of eggs in a clutch had no effect on the egg size.

Department of Nature Conservation, Maria CurieSkłodowska University, Akademicka 19, 20-033 Lublin, Poland; e-mail: mpolak@hektor.umcs.lublin.pl
\end{abstract}

Received 23 February 2010, Accepted 30 March 2010, Editor: J. Waldenström

\section{Introduction}

In birds, egg size is of major importance for individual reproductive success (Blackburn 1991, Nager \& Zandt 1994). In many studies special attention has been given the adaptive significance of intra-clutch egg size variability, since egg size may influence the condition of the chick at hatching time and hence its survival (Custer \& Frederick 1990; Swennen \& van der Meer 1992). The Marsh Harrier Circus aeruginosus is a medium-sized raptor species, almost exclusively breeding on the ground, mostly in flooded emergent vegetation, but also in arable fields (Glutz et al. 1979, Stanevičius 2004). This short paper describes the variation in size of Marsh Harrier eggs and examines the effect of clutch size and season on egg size variation.

\section{Material and methods}

Fieldwork was carried out at eleven fishpond complexes in eastern Poland in 2005-2008: Antopol, Chodel, Czesławice, Garbów, Kraśnik, Niedrzwica, Opole Lubelskie, Orlicz, Piaski, Samoklęski, Zalesie (Lublin region, N 50 $55^{\prime}-51^{\circ} 29^{\prime}$; E $21^{\circ} 58^{\prime}-$ $\left.23^{\circ} 10^{\prime}\right)$. The fishponds varied in size from 15 to 203 ha and were partially covered by vegetation, mainly dominated by common reed Phragmites australis, narrow-leafed cattail Typha angustifolia and sedges Carex sp. The ponds were situated in an agricultural landscape dominated by arable fields, meadows and woodlots of different ages. The Marsh Harriers nested in small, isolated patches of reed in the reed belt surrounding the ponds. Emergent vegetation in the fishponds was checked regularly (at least once a week) from the end of April to early July each year, and nests were located by systematic walking within the vegetation. A total of 70 nests with complete clutches were found. The length and width of each egg $(n=328)$ was measured with a calliper to the nearest $0.1 \mathrm{~mm}$. Egg volume was estimated by the equation of Hoyt (1979): volume $=0.00051 \times$ length $\times(\text { width })^{2}$. Only eggs from complete clutches and no replacement clutches were chosen for analysis. Statistical data processing was performed using STATISTICA 6.0 package (Statsoft Inc. 2001).

\section{Results and discussion}

The Marsh Harriers' clutches contained 3 to 7 eggs (Figure 1), with a mean clutch size of $4.69 \pm 0.71$ eggs, and a modal clutch size of 5 eggs $(n=70)$. There were no differences in clutch size between years (Kruskal-Wallis test, $\mathrm{H}_{3,70}=4.45, \mathrm{P}=0.22$ ), although such effects have been found in other 


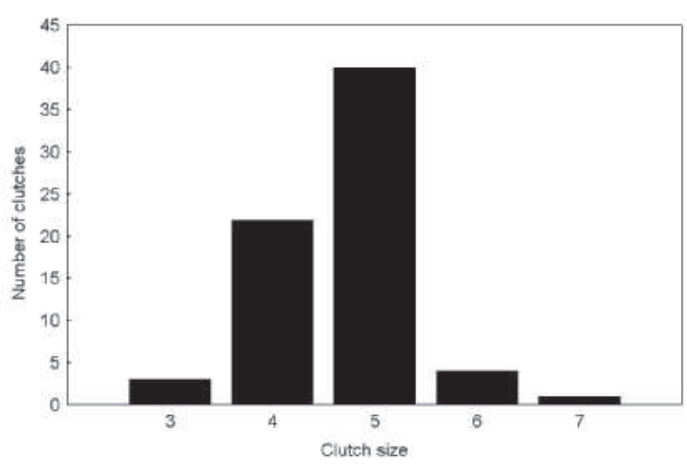

Figure 1. Frequency distribution of clutch sizes in Marsh Harrier nests $(n=70)$.

Frekvensfördelning för kullstorlek hos brun kärrhök.

populations (Witkowski 1989, Dijkstra \& Zijlstra 1997). In the Netherlands, clutch size decreased significantly in 1975-1995 and was negatively associated with laying date (Dijkstra \& Zijlstra 1997). The average clutch size was similar to or in the upper range of what has been described in other European studies. For instance, average clutch size in our study was smaller than recorded in the Barycz valley in SW Poland (5.0; Witkowski 1989), similar to that reported in Finland (4.66; Cramp 1980) and in the Netherlands (4.59-4.68; Dijkstra \& Zi-

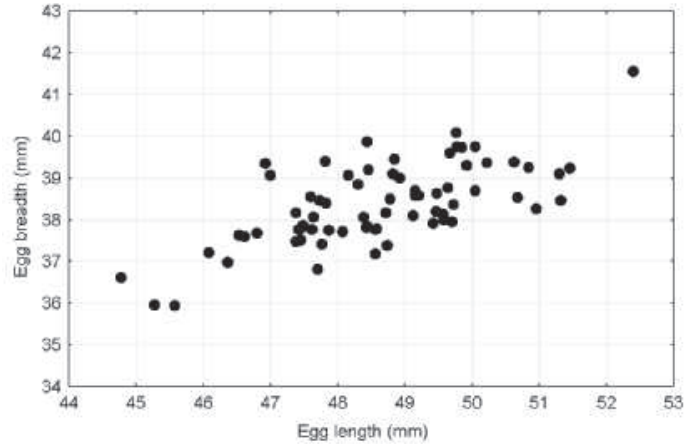

Figure 2. Correlation between within-clutch mean values of egg length and egg breadth in the Marsh Harrier $(n=70)$. Korrelationen mellan kullmedelvärdena för äggens längd och bredd hos brun kärrhök.

jlstra 1997), and larger than the average clutch size recorded in Czech Republic (4.06-4.24; Němečková et al. 2008). In general, clutch size is related to food conditions (Lack 1966), and one could argue that the food resource in our study population was stable during study period. Clutch size could also potentially be influenced by the polygynous breeding system of the species. For instance, in a population of Marsh Harriers in Kristianstad, southern Sweden, some large clutches have been recorded which included eggs from more than one female

Table 1. Mean values and ranges of egg measurements in Marsh Harrier recorded at fishponds in eastern Poland in 2005-2008.

Medelvärden och variationsbredd för äggmått hos brun kärrhök vid fiskdammar i östra Polen 2005-2008.

\begin{tabular}{llll}
\hline & $\begin{array}{l}\text { Mean } \pm \mathrm{SD} \\
\text { Medel }\end{array}$ & \multicolumn{2}{l}{ Range Variationsbredd (min-max) } \\
\cline { 3 - 4 } & & $\begin{array}{l}\text { Clutch means } \\
\text { Kullmedel }(\mathrm{N})\end{array}$ & Eggs Ägg $(\mathrm{N})$ \\
\hline Length Längd $(\mathrm{mm})$ & & & \\
2005 & $48.99 \pm 1.37$ & $46.62-52.40(25)$ & $44.8-54.2(121)$ \\
2006 & $48.16 \pm 1.68$ & $44.78-51.30(24)$ & $39.8-52.2(108)$ \\
2007 & $48.82 \pm 1.45$ & $46.36-51.45(14)$ & $45.6-52.5(64)$ \\
2008 & $48.45 \pm 1.41$ & $46.08-49.72(7)$ & $45.8-51.4(35)$ \\
\hline Breadth Bredd $(\mathrm{mm})$ & & & \\
2005 & $38.81 \pm 0.97$ & $37.37-41.55(25)$ & $36.3-42.2(121)$ \\
2006 & $37.91 \pm 0.95$ & $35.94-39.36(24)$ & $32.5-40.3(108)$ \\
2007 & $38.48 \pm 0.89$ & $36.98-39.86(14)$ & $36.3-40.6(64)$ \\
2008 & $38.09 \pm 0.48$ & $37.20-38.58(7)$ & $36.5-39.2(35)$ \\
\hline Volume Volym $\left(\mathrm{cm}^{3}\right)$ & & & \\
2005 & $37.70 \pm 2.72$ & $33.57-46.14(25)$ & $32.5-47.2(121)$ \\
2006 & $35.39 \pm 2.75$ & $30.02-40.00(24)$ & $21.4-41.3(108)$ \\
2007 & $36.93 \pm 2.49$ & $32.33-40.38(14)$ & $31.6-42.1(64)$ \\
2008 & $35.88 \pm 1.74$ & $32.53-37.32(7)$ & $31.3-38.7(35)$ \\
\hline
\end{tabular}


(Roine Strandberg, personal communication). Similarly, at Samoklęski fishponds a probable case of polygyny was recorded by Nieoczym (2006). In our study, we did not detect any suspected cases with eggs from more than one female.

The egg dimensions were as follows: mean egg length $=48.60 \pm 1.78 \mathrm{~mm}(n=328)$, mean egg breadth $=38.36 \pm 1.13 \mathrm{~mm}(n=328)$ and mean egg volume $=36.53 \pm 2.99 \mathrm{~cm}^{3}(n=328)$. Mean egg size values were similar to those reported in other studies (Glutz et al. 1979, Cramp 1980, Fefelov 2001). The studied eggs were smaller than noted in The Netherlands (Glutz et al. 1979) and in northwestern Russia (Fefelov 2001). They were very similar to those originating from the Barycz valley in southeastern Poland (Witkowski 1989) and Belgium (Glutz et al. 1979). Egg breadth (ANOVA; $F_{3,66}=4.28, \mathrm{P}<0.01$ ) and egg volume (ANOVA; $\left.F_{3,66}=3.45, \mathrm{P}<0.01\right)$ varied between years, but there was no difference between years in egg length (ANOVA; $F_{3,66}=1.36, P=0.27$, Table 1). Posthoc tests indicated significant differences between eggs measured in 2005 and 2006 (Tukey test, $P<$ 0.01 for egg breadth and $P<0.05$ for egg volume). These results were surprising, because parameters that contribute to egg volume and egg length are generally more variable than egg breadth, which is thought to be limited by the diameter of the oviduct (Surmacki et al. 2003). Generally, the breadth of an egg is determined by the anatomy of the female, the egg volume by her physiology, and the egg length represents the proportion between these two traits (van Noordwijk et al. 1981). In birds, the differences in egg size are related to differences between females, which are in turn are linked to individual or environmental conditions (Swennen \& van der Meer 1992, Nager \& Zandt 1994). The correlation between egg length and egg breadth was highly significant (Pearson's correlation; $\mathrm{r}=0.68, P<$ $0.0001, n=70$; Figure 2). This finding seems to be a more general rule and has been reported for many avian species (Mitrus \& Rogala 2001, Zduniak \& Antczak 2003, Profus et al. 2004). The largest eggs were found in clutches with four eggs (Figure 3), but egg dimensions (length, breadth and volume) did not vary significantly with clutch size (ANOVA; $\left.F_{6,97}=1.12, F_{6,97}=0.24, F_{6,97}=0.30, \mathrm{~ns}\right)$. Witkowski (1989) found that the number of eggs in a clutch had no effect on their weight. Life history theory predicts a trade-off between the number and the size of propagules produced (Blackburn 1991). However, in our study we did not find a correlation between egg dimensions and clutch size, and also other recent studies show that clutch and egg size
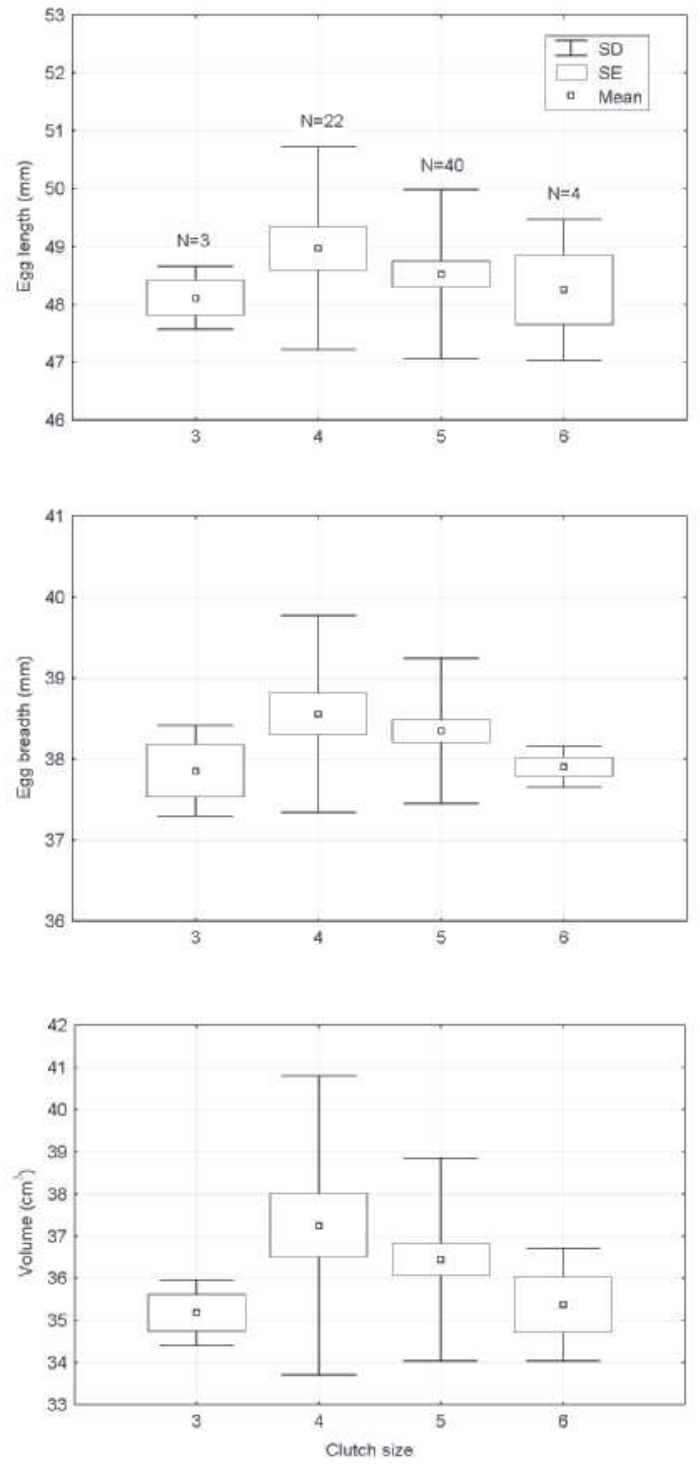

Figure 3. Variation in egg dimensions with clutch size in Marsh Harrier.

Variationen hos äggstorlek i förhållande till kullstorlek hos brun kärrhök.

can be independent of each other in birds (Mitrus \& Rogala 2001, Zduniak \& Antczak 2003, Surmacki et al. 2003, Profus et al. 2004). Thus, our findings do not support predictions based on the hypothesis of optimal egg dimensions dependent on a negative relationship between clutch and egg size (Blackburn 1991). 


\section{Acknowledgments}

I am most grateful to Jonas Waldenström and Roine Strandberg for the comments on an earlier draft of the manuscript.

\section{References}

Blackburn, T.M. 1991. An interspecific relationship between egg size and clutch size in birds. Auk 108: 209-211.

Cramp, S. \& Simmons, K.E.L. 1980. The Birds of Western Palearctic. Vol. 2. Oxford Univ. Press, Oxford.

Custer, T.W. \& Frederick, P.C. 1990. Egg size and laying order of Snowy Egrets, Great Egrets and Black-crowned Night-herons. The Condor 92: 772-775.

Dijkstra, C. \& Zijlstra, M. 1997. Reproduction of Marsh harriers Circus aeruginosus in recent land reclamations in the Netherlands. Ardea 85: 37-50.

Fefelov, I. V. 2001. Comparative breeding ecology and hybridization of Eastern and Western Marsh Harriers Circus spilonotus and C. aeruginosus in the Baikal region of Eastern Siberia. Ibis 143: 587-592.

Glutz, U.N., Bauer, K. \& Bezzel, E. 1979. Handbuch der Vögel Mitteleuropas. B.4. Wiesbaden.

Hoyt, D.F. 1979. Practical methods of estimating volume and fresh weight of bird eggs. Auk 96: 73-77.

Lack, D. 1966. Population studies of birds. Oxford.

Mitrus, C. \& Rogala, B. 2001. Egg size variation in the Collared Flycatcher Ficedula albicollis in the Białowieża Forest (NE Poland). Acta Ornithologica 36: 7-12.

Nager, R.G. \& Zandt, H. S. 1994. Variation in egg size in Great Tits. Ardea 82: 315-328.

Němečková, I., Mrlík, V. \& Drozd, P. 2008. Timing of breeding, habitat preference and reproductive success of marsh harriers (Circus aeruginosus). Biologia 63: 1-5.

Nieoczym, M. 2006. A probable case of polygyny in the marsh harrier Circus aeruginosus. Kulon 11: 111-113. (in Polish).

Profus, P., Tryjanowski, P., Tworek, S. \& Zduniak, P. 2004. Intrapopulation variation of egg size in the White Stork (Ciconia ciconia) in southern Poland. Polish Journal of Ecology 52: 75-78.

Stanevičius, V. 2004. Nest-site selection by Marsh Harrier (Circus aeruginosus) in the shore belt of helophytes on large lakes. Acta Zoologica Lituanica 14: 47-53.

Statsoft Statsoft Inc. 2001. Statistica for Windows (data analysis system), version 6. www.statsoft.com

Surmacki, A., Stępniewski, J. \& Zduniak, P. 2003. Repeatability of egg dimensions within the clutches of Bearded Tit Panurus biarmicus. Acta Ornithologica 38: 123-127.

Swennen, C. \& van der Meer, J. 1992. Variation in egg size of Common Eiders. Ardea 80: 363-373

van Noordwijk, A.J., Keizer, L.C.P., van Balen, J.H., Scharloo, W. 1981. Genetic variation in egg dimensions in natural populations of Great Tit. Genetica 55: 221-232.

Witkowski, J. 1989. Breeding biology and ecology of the Marsh Harrier (Circus aeruginosus) in the Barycz Valley, Poland. Acta Ornithologica 25: 223-320.
Zduniak, P. \& Antczak, M. 2003. Repeatability and withinclutch variation in egg dimensions in a Hooded Crow Corvus corone cornix population. Biological Letters 40: $37-42$.

\section{Sammanfattning}

Hos fåglar är äggens storlek av betydelse för häckningsframgången eftersom storleken kan påverka ungarnas kondition och överlevnad efter kläckningen. Det finns dock en konflikt mellan äggstorlek och kullstorlek eftersom honans kondition bl.a. via födotillgången kan påverka hennes läggförmåga. En hypotes om optimal kullstorlek förutsäger därför att det skall finnas ett negativt samband mellan äggstorlek och kullstorlek.

I denna studie redovisar jag kullstorleken samt äggens längd, bredd och volym för 70 kullar med inalles 328 ägg hos bruna kärrhökar som häckade i vassar vid fiskdammar i Lublin-regionen i östra Polen åren 2005-2008. Medelvärden och spridning för äggmåtten visas i Tabell 1 och fördelningen av kullstorlekarna i Figur 1.

De vanligaste kullstorlekarna var fyra och fem ägg, medelvärdet 4,7 ägg. Det fanns ingen signifikant variation i kullstorlek mellan åren, vilket man dock funnit i andra populationer. Detta kan ha berott på att födotillgången var lika god alla fyra åren. Kullstorleken var med mindre variationer ungefär densamma som man funnit i andra bestånd i Europa.

Äggmåtten var också med bara mindre variationer likartade de som rapporterats från andra delar av Europa. Äggens bredd och volym men inte längden varierade signifikant mellan åren. Största effekten kom från en skillnad mellan åren 2005 och 2006. Resultatet var överraskande. Det brukar nämligen normalt vara längden som varierar mest eftersom bredden begränsas av honans äggledare. Allmänt anser man att äggets bredd bestäms av honans anatomi och volymen av hennes kondition, varefter längden blir ett automatiskt resultat av dessa två storheter. Det fanns en stark korrelation mellan äggens bredd och längd (Figur 2), något som är regel hos fåglar. Visserligen fanns de största äggen i kullar av den vanligaste kullstorleken (Figur 3), men en ANOVA-analys visade att det inte fanns något signifikant samband mellan kullstorlek och vare sig längd, bredd eller volym. I denna studie fann jag således inget stöd för hypotesen om att större kullstorlek ger mindre ägg och vice versa. 